\title{
DEVELOPING FINTECH AND ISLAMIC FINANCE PRODUCTS IN AGRICULTURAL VALUE CHAIN
}

\author{
R. Gratiyana Ningrat ${ }^{1}$ and Mohamad Soleh Nurzaman ${ }^{2}$ \\ ${ }^{1}$ Universitas Indonesia, Indonesia, r.gratiyana@ui.ac.id \\ ${ }^{2}$ Universitas Indonesia, Indonesia, dedenmsn@gmail.com
}

\begin{abstract}
To meet the global population needs, it is projected at least eighty billion dollars in investment per year to support the food security until 2050. Arguably, the agriculture financing growth has stalled due to many reasons, while Islamic finance has the potential to spur the growth of agriculture financing to promote global food security. Meanwhile, agriculture in Indonesia is still nowhere to its potential. It is hindered by an inefficient and underdeveloped downstream segment, low access to financial and technology. This is a huge opportunity for Islamic finance in helping to bridge the gap through value chain financing approach as one of the strategies to reduce risk and provide socio-economic spillover effect along the chain. Islamic finance could promote agricultures sustainability and a more efficient process with FinTech enabled platform. The multiple case studies propose a sharia compliant community-based financing model in agricultural value chain practice with FinTech enabled platform. The result is this model integrating all actors from different market segmentation, including landowners, suppliers, farmers, brokers, retailers, and investors into an Islamic value chain-financing platform. However, determining buying intention, partnership establishment, and technology infrastructure are pivotal for its future implementation.
\end{abstract}

Keywords: Agriculture, Value Chain Finance, Financial Technology, Islamic Finance. JEL Classification: G23; O13; Q14; Q16.

\author{
Article history: \\ Received : September 5, 2019 \\ Revised : Oktober 4, 2019 \\ Accepted : Oktober 10, 2019 \\ Available online : November 1, 2019
}

https://doi.org/10.21098/jimf.v5i3.1077 


\section{INTRODUCTION}

\subsection{Background}

The global population continues to grow each year, and the demand for agriculture with current existing farmers is projected to increase by seventy percent in 2050 or at least eighty billion dollars in investment per year. However, the agricultural financial market has stalled due to several reasons: (1) Inappropriate and/or ineffective policies, (2) high operational costs to reach remote rural population, (3) covariance between production, market, and the risk of price, (4) the absence of risk management instruments, (5) low demand level due to fragmentation and new development in the value chain, and (6) lack of expertise of financial institution in managing agricultural loan portfolio (Varangis, 2018). In 2018, Indonesia addresses special issue on poverty alleviation in rural areas and agriculture where $30.58 \%$ of Indonesian employment working in this sector. It is estimated based on Indonesia Bureau of Statistics (BPS, 2019), 25.14 million people live below the poverty line and most of them living in rural region where agriculture still pivotal to make a living. Therefore, agriculture sector cannot be separated from development agenda especially for poverty eradication. Indonesia has a great progress in agriculture but the progress of smallholder farmers remains low in productivity. Currently, Indonesia's global food security index ranks 65 out of 113 countries one of the challenges is lack of public expenditure for agriculture research and development. Due to limited access to credit and inputs, smallholder farmers still vulnerable to market price fluctuation (Oxford Business Group, 2018). Consequently, the focus of Indonesian government policy is to provide fertilizer subsidy, grant of agricultural supplies, and machinery instead of research and development.

Above-mentioned problems stilloccurred in the digital era where the complexity is exacerbating the effect to the poorest of the poor. The needs for new approaches for solving the emerging problems in the Fourth Industrial Revolution to create new practices in social entrepreneurship with digital technologies are essential (Prodanov, 2018). Thus, the demand for innovative financing for agricultural sector is remain prevails and Financial Technology (FinTech) could promote financial inclusion as well as high-value agriculture because it enhances the ability to objectively quantify variation to directly conducive to the shifting of risks in the agricultural system (McIntosh \& Mansini, 2018). Moreover, Islamic finance' asset projected to 3.5 trillion dollars in 2021 while the SDGs agenda needed 2.5 trillion dollars investment to reach its goals (Salıngan, 2018). It depicts the importance of Islamic finance contribution to global development agenda. The unique properties of Islamic finance which have a balance component in commercial, social, and spiritual (Moh'd, Omar Mohammed, \& Saiti, 2017; Obaidullah, 2015; Oladokun, Larbani, \& Mohammed, 2015; Saqib, Zafar, Roberts, Zafar, \& Khan, 2014) similarly to the nature of agricultural value chain finance that blending commercial and social to increase the welfare for all actors along the chain.

Social enterprises see agriculture as an opportunity to disruption and one of the issues is lack of access to financial sources. Indonesia is the third largest smartphone market in Southeast Asia, but half of the population is unbanked and only acquires only $85 \%$ of the country's transaction (ANGIN, 2016). FinTech social enterprises have started to emerge to create innovative solution to the market especially to accelerate the financial inclusion to reach out more to rural areas. 
Digital finance for agriculture is still a pristine area of research although several current issues has been addressed, such as digital inclusion for smallholder farmers (Agyekumhene et al., 2018), the role of Fintech platform in agribusiness (Hinson, Lensink, \& Mueller, 2019), also food security platform model (Anshari, Almunawar, Masri, \& Hamdan, 2019). Unfortunately, very little research has been done in Islamic finance with Fintech platform enabled for agriculture value chain despite the growing interest in digital finance from Islamic perspective (Todorof, 2018). In addition, according to Indonesian Financial Service Authority (OJK, 2019) only 9 out of 127 FinTech registered are sharia compliant, creating plenty of room to develop Islamic FinTech in Indonesia. For such reasons, the opportunity of Islamic FinTech to grow the agriculture value chain financing remains as the main topic of the research.

\subsection{Objective}

This study proposes a sharia-compliant community-based and institutional financing with Fintech platform integrating all actors including suppliers, farmers, brokers, retailers, investors, and institutions) into an Islamic value chain financing where digital platform is adopted to enabling the whole business process, improve transparency, accessibility, and sustainability within the agriculture's ecosystem.

\section{LITERATURE REVIEW}

\subsection{Agricultural Value Chain Financing}

The agriculture business process links several actors along the chain to different markets. Figure 2 illustrates the most common process, market segmentation, and actors in AVCF (Agricultural Value Chain Financing). The most common investors and funders in AVCF are individuals (crowdfunding), institutional fund (nonprofit, foundation, zakat, waqf), non-bank financial institutions (microfinance institution, insurance), and banks. Overall, the business process divided into four layers, input, production, intermediation (brokerage and retail), and finally consumer. Each market segment has different actors involved. This segmented value chain depicts the different process, layers, and cost needed to deliver the product meaning the financial needs will vary across the actors and market segments.

AVCF (Agricultural Value Chain Financing) is one of innovative way of financing to improving the agriculture's business process. The smallholder farmers are not only need access to finance and technology but also the access to other actors along the chain such as brokerage, traders, and financial institution to increase the production competitiveness, processing, marketing, and distribution (Meyer, 2007). Various frameworks for the value chain of agricultural finance have differences in the views of local to international trade. Each value chain has different risks, returns, and financing schemes so it requires financial instruments to get optimum social and profit impact (Shwedel, 2007). Several external factors such as push and pull factors, technology, regulation, and standardization could provide challenges and opportunities. Providing financial access is only one of the services provided in the agricultural value chain, besides that there is market 
information, market identification, marketing, and policy. Cooperation is needed between various actors such as the government, NGOs, agricultural extension agents, international development agents, and one of them is financial institutions (Digal, 2007). Through this approach, it is imperative for financial institution to gain critical information about the borrowers from various sources within the chain. The financial services offered to value chain actors are tailored based on vertical and horizontal process which lead to cost and risk reduction and increased the repayment rate (Casuga et al., 2008; Miller \& Jones, 2010). This approach supports the segmented agriculture's value chain needs of fund by increase the access to finance likewise access to other actors across market.

\subsection{Islamic Financial Technology}

Technology is necessary to establish data that are more transparent and transaction along the chain, all to enable the agricultural value chain finance processes. It is widely known that technology has been the backbone for financial services development. The emerging Fintech platform offers an innovative way by combining speed and flexibility capabilities to deliver products and services with a more customer-centric experience compared to the traditional methods (Nicoletti, 2017). Fintech platform could increase the transparency and sustainability to support AVCF goals by streamlining the financial process from different types of investors. Individual investors could directly invest actors' proposed fund only through FinTech platform. Fintech platform could also address asymmetric information, institutional investors could obtain data \& information of borrowers more precisely backing with advanced technology in FinTech development i.e. artificial intelligence, machine learning, and block chain. Even, some features could decrease operational cost in transaction i.e. digital money, mobile wallet, RegTech, InsurTech, and payment services (Lynn, Mooney, Rosati, \& Cummins, 2019).

The difference between Islamic and conventional finance is it operates with Islamic sharia compliant i.e. prohibition of riba (interest or usury), gharar (excessive uncertainty), maysir (unearned income). Although it is relatively new in financial industry Islamic finance continues demonstrate its competitiveness in the face of economic crisis and stagnation. This increase the demand for developing innovative financial instruments and services to address contemporary challenges in this fourth industrial revolution while still comply with Islamic sharia (AlSalem, 2009). As far as authors' knowledge, there is no specific concept about how Islamic Fintech platform could be different with the mainstream. However, to address sharia and FinTech seems counterintuitive and questionable whether it could coexist with and benefit from its innovation. Islamic finance considers public interest (maslahah), relieving hardship for poverty alleviation, and make policy which encapsulates risk and harm while technology could bring greater transparency and efficiency such as P2P and blockchain (Todorof, 2018). 


\subsection{Previous Studies}

Agricultural value chain finance is widely used for develop and enhance the business process in agriculture sector. Due to its complexity and usefulness, such an approach is usually discussed in agricultural development area although a number of undocumented practices occur in some developing countries. There are several papers about the development of agricultural value chain finance approach (Meyer, 2007; Shwedel, 2007) or book of journals related to this financing to the rural farmers (Digal, 2007; Mani, Joshi, \& Ashok, 2017) also the practical guideline to this approach (Miller, 2012; Miller \& Jones, 2010). Most agriculture value-chain analyses use interdisciplinary approach to develop the market and products. This study aims to develop Islamic AVCF through different case studies of development sector and FinTech platform.

This financing scheme generally embedded with market system development to promote welfare of smallholder farmers and recent studies investigate this form of cooperation and development (Kuhl, 2018; Rankin, Nogales, Santacoloma, Mhlanga, \& Rizzo, 2018). Khul (2018) stated that market system development could be integrated with climate resilience agenda beyond the agriculture sector. The approaches will create compelling synergies if the tension between resilience and market system could be settled by focus on identifying climate change effect to the market system. Both Value Chain Development (VCD) and Market System Development (MSD) are most common method in Public-Private Partnership (PPP) where the project expected to have high socio-economic spillover. However, there is key risk where this project fails to address the poorest of the poor due to the nature of private partner to lessen the transaction cost. This paper investigates how Islamic private actors have potentials to serve the underserved market with digital platform model.

In the era of digital revolution, some recent studies about innovation and digital technologies in agriculture finance have been carried out by Agyekumhene et al. (2018) and Anshari, Almunawar, Masri, \& Hamdan (2019). Agyekumhene et al. (2018) suggest digital platform shows potential to generate new form of network and cooperation in a complex configuration of actor interaction in traditional value chain financing based on their findings in maize farmer in Ghana. The important fact to harnessing the digital platform is not only about digital inclusion and about access for farmer but also effective intermediation and network governance in agriculture ecosystem. In addition, Anshari et al. (2019) develop a platform to integrate agriculture business process to various actors. As such, the platform uses smartphone as a general-purpose device to facilitate all business transaction. The digital marketplace is expected to attract all actors with personalized services, improve market price transparency, and digital payment to promote the sustainability of agriculture ecosystem. Both studies depict the role of digital platform to finance the agriculture business and provide solution from technical process aspects. Hence, this paper accommodates from financial products, development, and business partnership perspective to prove Fintech platform will bring solution to agriculture business actors and stakeholders.

In contrast, it is rare to find some reference of this financing approach from Islamic perspective. Most of the studies are investigate the Islamic microfinance practice in agriculture (Obaidullah, 2015) or appropriate modes of finance in some 
specific case and area (Moh'd et al., 2017; Oladokun et al., 2015; Saqib et al., 2014) although agricultural value chain finance is quite mainstream in agriculture and development sectors. Obaidullah (2015) undertakes a review of various Islamic microfinance interventions in agriculture where it is strongly argued how the conventional products and services are not acceptable in the Islamic societies. It is also found that, there is no one-size-fits-all mode of finance in agriculture sector. For instance, Saqib et al. (2014) suggest types of musharaka with the concepts of muzara'a and musaqa to finance agriculture in Pakistan particularly in urban areas as compared to rural areas but still push Islamic banks to work for prosperity of the poor. Oladokun et al. (2015) develop a Muzara'a supply chain model although it is similar with value-chain finance concepts through land partnership. In addition, Moh'd et al. (2017) use the waqf-linked muzara'a supply chain model as an alternative model to finance clove crop production in Zanzibar. All studies suggest traditional way of supply chain financing with quite complex procedure and do agree it will face challenges in implementation without mentioned technology support. Therefore, there is still gap in the financial technology in agriculture from Islamic perspective and how it could enhance the flexibility to design and offer the user centric product and services.

Therefore, it remains a puzzle what kind of Islamic finance model that could contribute the development of agricultural value chain finance in the era of digital technologies and how it could bring solutions? This paper investigates those previous findings concurrent with practical insights from market system development and agriculture financial technology platform to develop the Islamic agriculture value chain financing products based on current agriculture landscape in Indonesia.

\section{METHODOLOGY}

\subsection{Case Selection}

To begin this study and investigate how AVCF and market development works, we chose a multi-year public private partnership in agriculture rural market development, which established since 2013 as case study. This partnership involved various stakeholders for its program in agribusiness' market development, irrigation, research and development, and agricultural value chain financing. This program adopts a market system development and agricultural value chain finance approach to spur the growth of smallholder farmers and partners with private sector, local and national government, business associations, non-profit organization, and research institutions which aiming to benefit one million smallholder farming households in eastern Indonesia. For AVCF with FinTech platform we selected Crowde, an ecosystem builder for digitizing agricultural process from upstream to downstream through peer-to-peer lending mechanism established since 2015. Besides providing finances to smallholder farmers, Crowde also engaged input suppliers and off takers to build the sustainable agriculture ecosystem, provide access to technology, financial management education to equipping agricultural value chain actors to develop their businesses. Crowde disbursed fund to 10,000 farmers mostly in West of Indonesia from 22,400 lenders in 2018. Not only peer-to-peer lending mechanism, currently Crowde collaborated 
with banks and other institutions for B2B financing model. Both institutions are using conventional financing as their primary products. Crowde also launched their Islamic financing scheme for farmers in 2018. Therefore, from the cases which market and technology have been established could be incorporated in a modeling for Islamic FinTech enabled platform.

\subsection{Method}

\subsubsection{Case Study Method}

This study focuses on different agricultural value-chain finance practices. A case study method is useful method for preliminary investigation where AVCF with FinTech enabled platform is considering new field of study and how Islamic finance could provide solution in AVCF with FinTech enabled. The focus of case study is to explore "why" and "how" questions (Yin, 2014). The main goal of this study is to find Islamic finance products to provide solution in Fintech platform that use AVCF approach. We keep the anonymity of one of the institutions without diminishing the main goal of this study. This study investigates "why" and "how" the institutions implement agricultural value chain finance approach which are,

- Why agricultural value chain finance approach?

- How do the agricultural value-chain finance practices go about the market?

- What are current AVCF products and how is the transaction?

We use as case study to investigate AVCF process, transaction, and market based in non-technology based and FinTech enabled platform on figure 1 framework. A case study could be a practical solution with purposive sampling when a big sample population is difficult to obtain. Multiple case studies approach provides the potential for generalizability of findings (Miles \& Huberman, 1994). Due to the triangulation evidence this method provides a more rigorous approach than a single case study (Yin, 2014). Case study is use to answer the research question with qualitative analysis approach from institutions' public report and interview. Then, based on AVCF process, transaction, and market results we investigate from Islamic finance product in agriculture, contract, and trade financing. The outcomes of Islamic agricultural finance solutions are also evaluated from product management perspective without compromising Islamic financial product innovation (Todorof, 2018). 


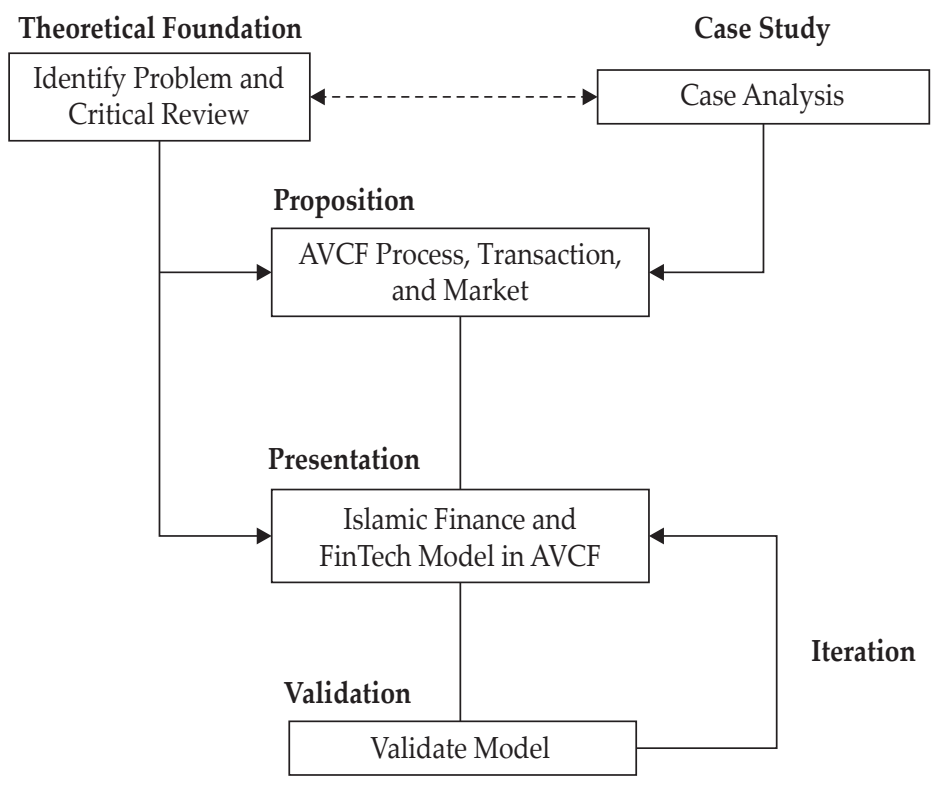

Figure 1.

Case Study Analysis Process by Authors

\subsubsection{Data Collection Method}

Following Krippendorff (2004) and Yin (2014), this study starts with data collection through purposive sampling where. In-depth interviews with product development, operation, and management team has been carried out to construct agricultural value chain finance and market development practices as well as agriculture FinTech as sources of primary data i.e. transcript, draws. Guided by a semi-structured protocol in which interview lasted approximately 90 minutes in average. Some internal and public document of the institutions also collected to support the qualitative data (Creswell, 2014). In addition, some publication and peer-reviewed journals on agriculture's value chain process and FinTech have acquired as secondary sources of data i.e. text, graphic as a supportive information on models. Then, the triangulation to validate different sources to understand different perspective from practical views and studies within of the same phenomenon in AVCF and Financial Technology in Agriculture. We used the thematic analysis to cluster the results into (1) process, (2) products, and (3) platform model combining with current literature in agriculture's Islamic finance and FinTech platform. Afterwards, we used the results to modeling the Islamic agricultural value chain finance in FinTech. An interview of experts along with other information provides an avenue to increase construct validity. The credibility of this study could be increased by prolonged engagement, triangulation, referential adequacy, peer debriefing, and member checks (Lincoln \& Guba, 1985). 


\subsubsection{Coding and Data Analysis}

The content analysis was chosen to analyze the agricultural value chain finance. Content analysis is a research method for making replicable and valid inferences from texts (or other meaningful matter) to the contexts of their use. This technique should result in finding that are replicable in time and different circumstances as the form of reliability (Krippendorff, 2004). The data sources comprise primary and secondary type of data and acquired in parallel to explore AVCF process, transaction, and market. Then each researcher compares all codes with coding in relevant literature, which leads to construct an agricultural value chain market for ACVF and market development theme also to add some features for technology development with an open method for coding. Then, we compare to agriculture FinTech case and do triangulation between the data acquired to build a model for Islamic product. Afterwards, the result consistently reviews and compared with corresponding descriptions and experts from product management perspective.

Table 1.

Coding Examples

\begin{tabular}{|c|c|c|c|}
\hline \multirow{2}{*}{ Category } & \multirow{2}{*}{ Codes } & \multicolumn{2}{|c|}{ Some Interview (translated to English) } \\
\hline & & Program & FinTech \\
\hline \multirow{2}{*}{$\begin{array}{l}\text { Reason } \\
\text { adopting } \\
\text { AVCF } \\
\text { Approach }\end{array}$} & $\begin{array}{l}\text { Information } \\
\text { along the chain }\end{array}$ & $\begin{array}{l}\text { "We can gain information } \\
\text { from local 'Toko Tani' (Input } \\
\text { Suppliers) about farmers' } \\
\text { historical transaction." }\end{array}$ & $\begin{array}{l}\text { "From farmers, we gain } \\
\text { information which local inputs and } \\
\text { off takers they often transact with." }\end{array}$ \\
\hline & $\begin{array}{l}\text { Improve farmers' } \\
\text { income }\end{array}$ & $\begin{array}{l}\text { "We have other program to } \\
\text { develop the market first before } \\
\text { financing. We select actors } \\
\text { and partners with us which } \\
\text { aiming to improve smallholder } \\
\text { farmers' income" }\end{array}$ & $\begin{array}{l}\text { "If we involved local input } \\
\text { suppliers and off takers with } \\
\text { us, we can also digitize the } \\
\text { agricultural ecosystem to improve } \\
\text { famers' productivity" }\end{array}$ \\
\hline $\begin{array}{l}\text { AVCF practice } \\
\text { in the market }\end{array}$ & $\begin{array}{l}\text { AVCF product } \\
\text { mechanism }\end{array}$ & $\begin{array}{l}\text { "We build a partnership with } \\
\text { local financial institution i.e. } \\
\text { cooperation or microfinance } \\
\text { institution and making a } \\
\text { customized product" }\end{array}$ & $\begin{array}{l}\text { "We propose farmers' project to } \\
\text { our platform for lenders. Mostly } \\
\text { we have already disbursed } \\
\text { to farmers' whether doing } \\
\text { partnership with local suppliers to } \\
\text { disburse in kind or cash directly to } \\
\text { farmers. There are also for off-taker } \\
\text { and input supplier" }\end{array}$ \\
\hline
\end{tabular}

\section{RESULTS AND ANALYSIS}

\subsection{AVCF and Market Development}

The relationship between AVCF and market development is the similar nature of both approaches to promote agriculture economic growth and welfare, which have been implement in the program of this case study. The Theory of Change as the base of this case is agriculture sector have strong poverty-alleviating effect where every increase of one-third in yield might reduce the poverty by a quarter (Irz, Lin, Thirtle, \& Wiggins, 2001) and three times more efficient in poverty eradication (World Bank, 2008). The program use market system development which to linking the poor to markets and use private sector intervention in poverty alleviation and economic growth (Donovan, Franzel, Cunha, Gyau, \& Mithöfer, 
2015). Market system development aim to improve farmers' access to market to increase their competitiveness as well as their income (Briones, 2015). One of problem to be addressed is access to formal finance of smallholder farmers in rural areas. The financial institutions are reluctant to enter this market because of their perspective about agriculture finance is not profitable, low repayment rate, and higher lending risk (Chen, Joshi, Cheng, \& Birthal., 2015). Hence, this program uses Value Chain Finance (VCF) approach to attract more stakeholders to form partnership. Value chain financing often requires a different attitude by financial institutions to integrate all value chain actors within the financing activities for instance individual farmers' loan analysis, the administration, and monitoring.

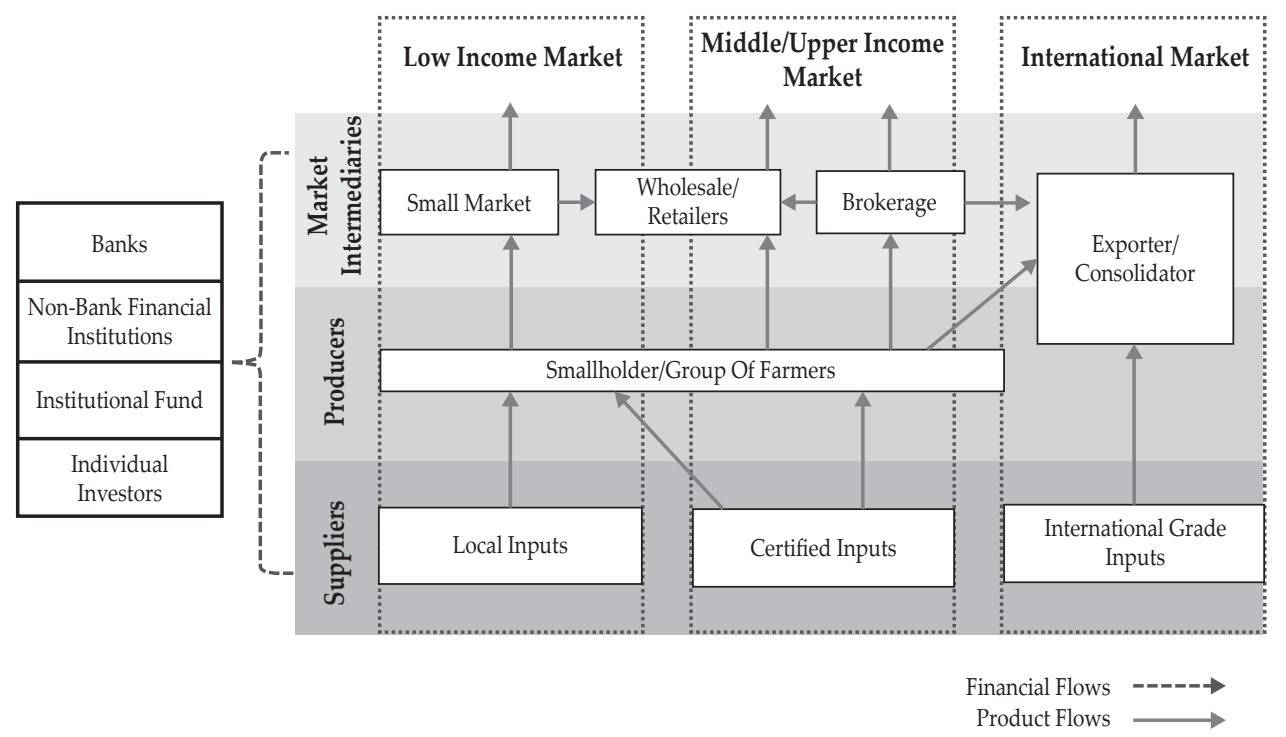

Source: Compiled by Authors', 2019

Figure 2.

Segmented Agriculture's Value Chain Finance

The other purpose to intervene the rural market is to drive traditional supply chain to modern value chain. Mostly in rural market, the production is in supply-led bulk and fragmented with high marketing costs and margins. The extension services are local agencies and financing from moneylenders, local suppliers, and traders, relative mostly to production. In contrast, modern value chain is market-driven and integrated, less number of market intermediaries, and financing internal and external chain (Casuga et al., 2008). There are three market segmentation generally in agriculture's value chain, poor/rural or low income market, middle/upper income market, and international market which interconnected and depicting the importance of value chain innovation (Jones, 2011) simplified in Figure 2. The way this program innovating agri-value chain with multi-stakeholder processes to promote the inclusiveness of smallholder (Kilelu et al., 2017) could be included in policy implication for Islamic FinTech platform. 


\subsubsection{Agriculture Financing Product}

Value chains differ with one another and could be classified into three types of business models which are (i) producers, (ii) buyers, and (iii) facilitators (Miller, 2012). A producer-driven value chain refers to upstream value chain actors (i.e. producers) where they organized and form a cooperative group or association to gain access to markets, to reduce marketing and transaction costs. Contract farming is a common form of buyer-driven chains, where traders, exporters, processors, retailers have control to the production process. By this type of model, the transaction costs of aggregation of scattered small marketable surpluses, to optimize the processing capacity and work force, and to meet market preferences of quality of harvest. To avoid monopolistic rent, the developmental organizations facilitate collective action to promote the market competitiveness for smallholder farmers (Gyanendra Mani \& Joshi, 2017). Such chains are termed as facilitatordriven. However, the implementation in Indonesia's rural market is quite paradox. The interviewee says the rural farmers have low productivity but not forming strong groups or association. The buyers are quite strong to drive agriculture market in rural area. To reduce risk, it is suggested to provide loan to the strongest actors along the chain (Meyer, 2007). Even though the program uses market system development, which means using facilitator driven model, this program use buyer-driven chains instead to strengthening the value chain finance due to market condition. Additionally, the program is just temporary means that to ensure the sustainability of market system development, it builds private and public partnerships. Before doing exit strategy, they evaluate the intervention reliance ratio whether the costs incurred are borne by partners more than the program cost or otherwise.

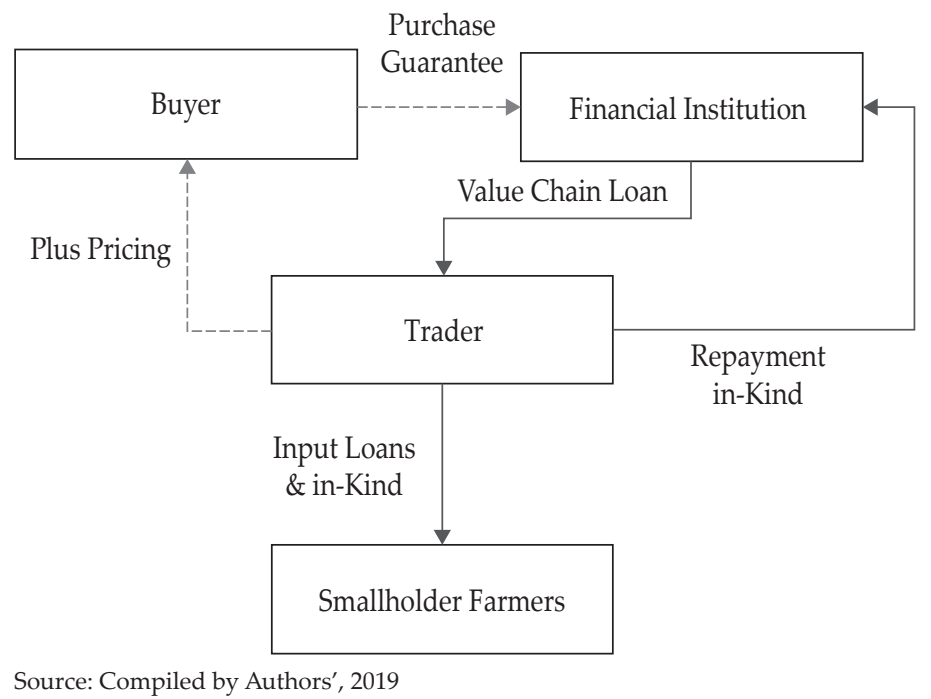

Figure 3.

Common Value Chain Financing Mechanism 
The common type of value chain financing in rural market is internal value chain when input supplier or trader provide credit to the smallholder farmer, which takes place within the value chain. On the other side, external value chain is the loan issued by a bank to farmers, which is made possible by value chain relationships and mechanism (Miller \& Jones, 2010). The program aim to shift the mechanism where microfinance institution, cooperation unit, and regional banks could provide loans to smallholder farmers and other value chain actors. The main reason is financial institutions have more capabilities to develop financing product compared to input suppliers and traders; hence it will restore the role of each actor. The VCF mechanism is different depends on the value chain actors' necessities and find the strongest and less risk actors within the value chain to build a partnership (Miller \& Jones, 2010). The reason why they still impose interest fee loan instead of profit-loss sharing is to reinforce the farmers' yield which expecting it will be more efficient in neutral shock condition (Sugema, Bakhtiar, \& Effendi, 2010).

\subsubsection{The Opportunities of Technology and Islamic Finance with Public-Private Partnership (PPP) project}

"The business model that we use is different in each areas and commodities. Mostly farmers have low self-confidence because of their low education level and its different depends on their capacity and their market segment"

The smallholder farmers linking into three different market segments: weekly or poor/rural market, middle to upper market, and international market (export). The market linkage is different between smallholder farmers depending on their capabilities in productivity, financial literacy, and access to technology. Internal financing between actors already happened in form of traditional supply chain e.g. input suppliers to farmers, off-takers to farmers before market intervention begin. To build market system in AVCF, they find the strongest actors, less risk, and have social value based driven to build a partnership. Collective action is essential, but it not may happen without intermediation by the nongovernmental organization, lead firms, or government intervention.

"We rarely intervene the low-income market due to the risk of daily fluctuation and transaction..."

There is an opportunity for Islamic social finance to low-income market. Nevertheless, this program aims to increase the livelihood of smallholder farmers even below the poverty line. They do not find any financial instrument to sustain the low-income segment. All financial products are using conventional loan, where loan shark could disadvantage the farmers i.e. pay high interest rate, pay less than market price before harvest. They assume interest rate loan will be more cost efficient instead of profit and loss credit because it will reduce technical assistance cost to ensure the return will be favorable.

"Usually we will ask the input suppliers about the historical transaction of several farmers. They remember the payment schedule and some profiling data for credit scoring"

The credit scoring process is still acquired manually from value chain actors' memory or unstandardized paper notes. It will increase bias depending on the ability to remember the historical transaction for their clients (farmers). Therefore, 
it needs data acquisition techniques with technology to gain comprehensive information about value-chain finances, and FinTech could record the historical transaction or acquire the initial data through daily business process.

\subsection{Agriculture FinTech}

To promote smallholder farmers' income, Crowde created a financial technology platform as the first digitalized agriculture ecosystem. The use of financial technology is to increase the financial inclusion of agriculture businesses through the ease of financial access with personalized services (Anshari et al., 2019; McIntosh \& Mansini, 2018). Through financial inclusion, it could increase their participation to the market which could help them to promote farmer's welfare (Casuga et al., 2008; Prabhakar, 2019). This platform encourages funders or lenders both individuals and institutions through crowdfunding could select wide-range of projects to invest their money in certain period. By linking all actors, it could create a more sustainable and integrated agriculture ecosystem (Anshari et al., 2019). The process is simple, to propose a fund, borrowers should provide project document to be assessed by Crowde. After being accepted, the project could be submitted and published within limited time into the platform where funders could choose the project. After the period of crowdfunding or the amount proposed has been fulfilled, borrowers could use the fund then will pay the principal and return when the project has finished.

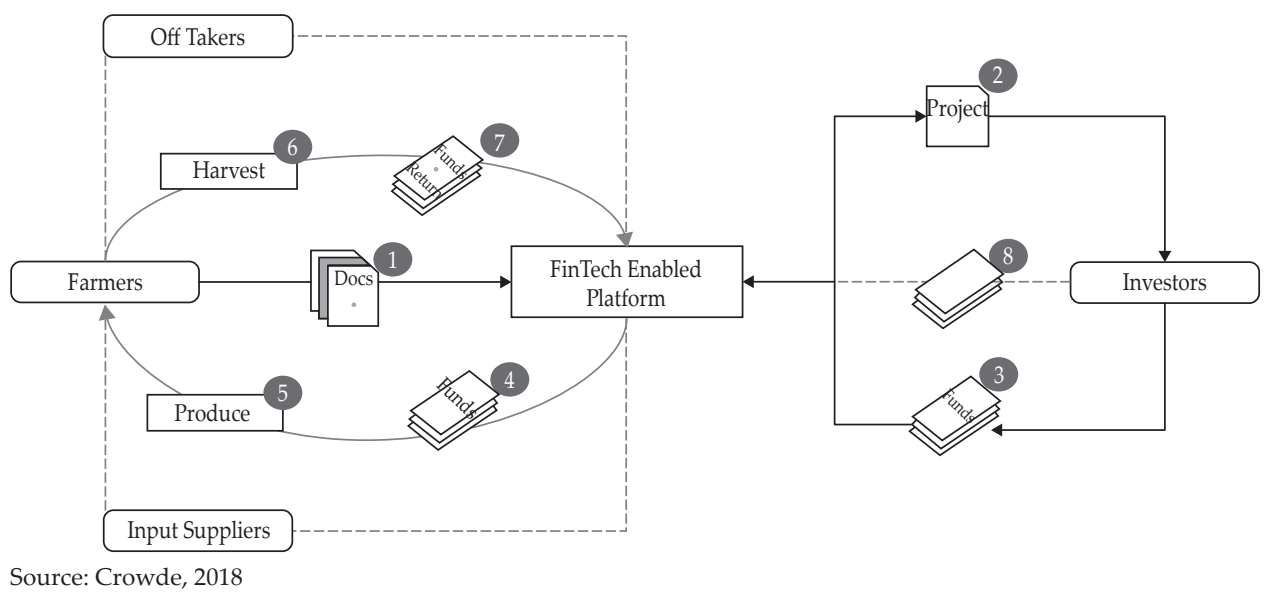

Figure 4.

FinTech Enabled Platform in Agriculture

Crowde created a collective mechanism with field officer to form a group of farmers based on location and act as an intermediary between farmers and Crowde to ensure value chain actors will get benefit from the system (Agyekumhene et al., 2018). Their main role is to ensure the data input, farming process, and funding collection run smoothly. Crowde developed several applications for each value chain actors who served by the platform. The data transaction between input 
suppliers, farmers, and off-taker would be integrated into one platform to be process as collective information to create insightful information, which could be shared to all actors. This technology could fill the gap for market development program where they still manually gathered all data from each value chain actors' network.

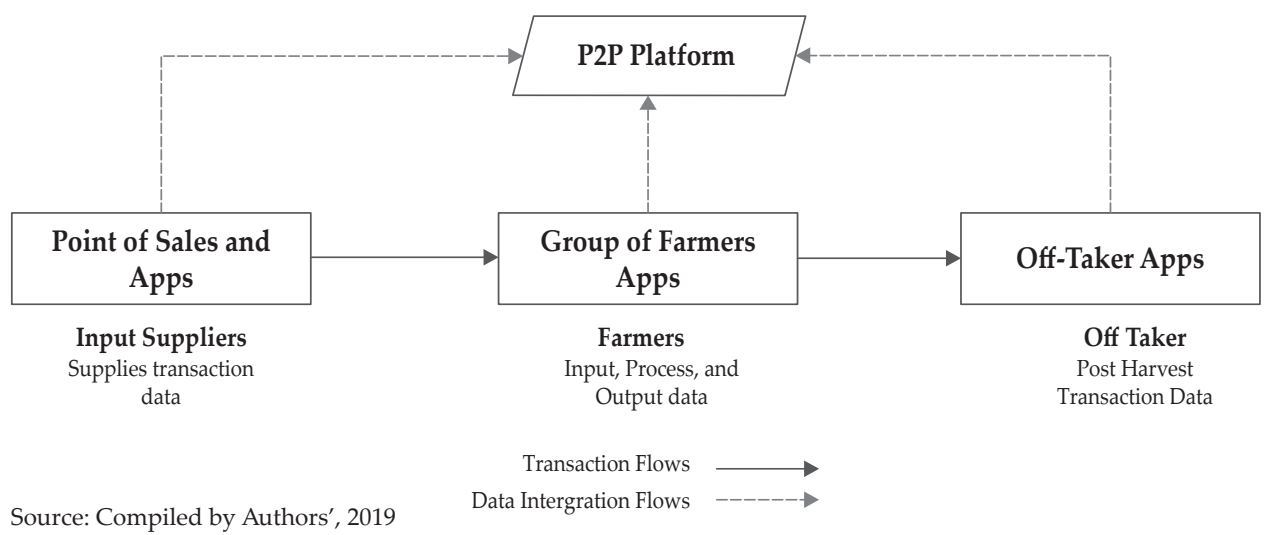

Figure 5.

Data Flows in FinTech Enabled Platform

\subsubsection{Agriculture FinTech Products}

As agriculture financial technology platform, Crowde has separate financial products in conventional and Islamic scheme. Conventional products have loan with interest rate and profit sharing mechanism without loss sharing. Meanwhile, Islamic products mainly in murabaha (cost sales plus) and musharaka (jointpartnership). Crowde acts as an intermediary between farmers and investors for disbursement and monitoring through field officer.

\section{a. Conventional Products}

The loan scheme is like credit loan in general where the borrower will pay principal and interest loan monthly. The disbursement process will be based on agreement whether based on cycle or once a month. The monthly rate is varied, mostly will charge $2-3 \%$ per month then the platform will get interest rate shared half with investors or 2:1 between investors and Crowde respectively.

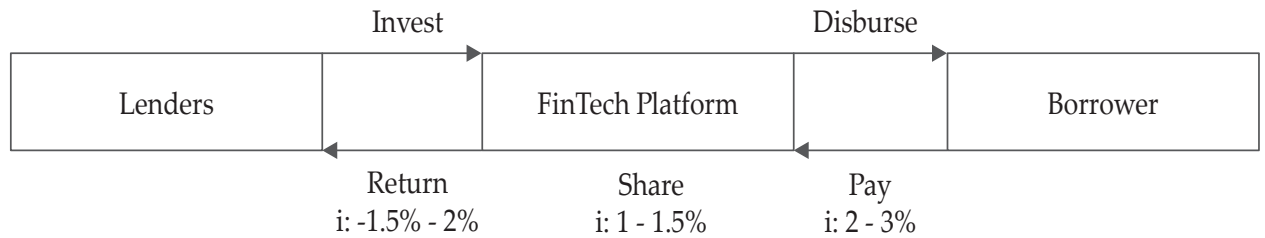

Source: Compiled by Authors', 2019

Figure 6.

Loan Scheme 
The most popular scheme among farmers is profit sharing where the payment return will be depending on their productivity income. The platform will disburse some percentage of loans deducted after management fee. The profit-sharing rate will be based on capital contribution between borrower and lender which around 60:40 respectively. If loss occurs, farmers should pay the labor cost. Both scheme have flexible payment based on harvest cycle, although it depends on the nature of commodities which is required to increase the adoption rate of formal lending instead of informal lending (Meyer, 2002). The flexible payment mechanism also increase the likelihood of farmers' access to credit and minimize the risk of seasonal horticultural commodities farmer (Weber, 2013) which took up the majority of Crowde's financing portfolio.

\begin{tabular}{|c|c|c|c|c|}
\hline \multicolumn{2}{|c|}{ Loan: 100\% } & & \multicolumn{1}{c}{ Fee: 3\% of Loan } & \multicolumn{2}{c|}{ Disburse Loan Value } \\
\hline Lenders & & FinTech Platform & & Borrower \\
\hline $\begin{array}{c}\text { Profit Sharing : } \\
30-40 \%\end{array}$ & Return & & Share & $\begin{array}{c}\text { Profit Sharing : } \\
60-70 \%\end{array}$ \\
\hline
\end{tabular}

Source: Compiled by Authors', 2019

\section{Figure 7.}

Profit Sharing Scheme

\section{b. Islamic Products}

Crowde also has Islamic finance product as an option for borrowers and lenders. Two modes of finance, murabaha (cost-plus sale), which means sales agreement, and musharaka (partnership), where lender and borrower share some proportion of project capital in certain farming period, play significant roles. Crowde acts as the brokerage or wakala between lenders/funders and borrowers where they will get some fee or ujra based on agreement in each transaction. Murabaha in this context is quite similar with internal financing from input supplier to farmers. FinTech platform will use the fund from lenders to buy input needed by borrowers. Then, chosen local input supplier will distribute in-kind product to borrowers and will pay the product with agreed price and payment schedule (Obaidullah, 2015). The payment schedule could be monthly based or deferred at the end of farming cycle full with principal and margin (agreed price). Lastly, the lenders will get the principal and return at the end of period.

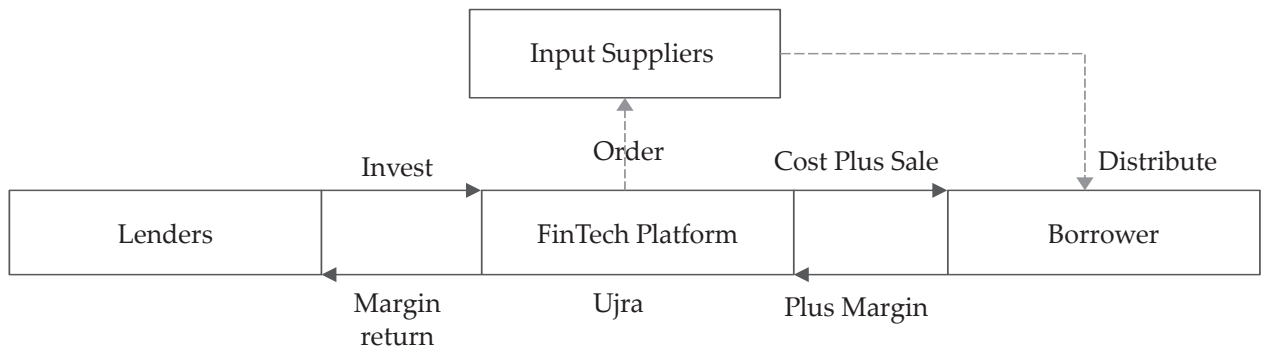

Source: Compiled by Authors', 2019 


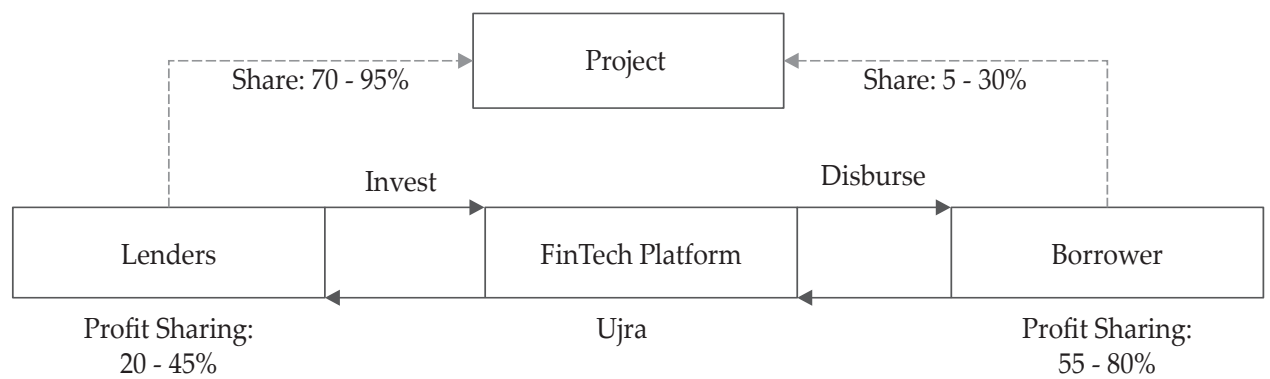

Source: Compiled by Authors', 2019

Figure 9.

Musharaka Scheme

Murabaha mechanism has low risk but not as popular as musharaka. The flexibility of funding usage such as to pay labor, rent, input, and processing cost is preferable than receive credit term only for farming inputs. Generally, funders will contribute $70-95 \%$ of the project value whereas borrowers have $5-30 \%$ proportion of fund. Then, profit and loss sharing term will be based on agreed upon the project. The profit range for funders is $20-45 \%$ and $55-80 \%$ for borrowers depend on risk assessment and fund proportion. Loss will be shared between funders and borrowers up to 50:50. Crowde will only get management fee whether based on fraction of fund or certain amount of fee. Despite the efficiency in musharaka scheme is always warranted between two parties (Sugema et al., 2010) smallholder farmers still reluctant to adopt Islamic finance as their source of financing due to lack of knowledge and awareness about the product compared to conventional loan (Abdul Rahman, Muhammad, Ahmed, \& Amin, 2016). The development of Islamic modes of finance in Crowde is on initial stage; therefore, to build awareness to increase adoption is important to be incorporated in support function and policy implication. In contrary with market system development program that focus on how to create the market work for the farmer with AVCF approach. Crowde operation is leaner by only providing working capital loan to farmers and assisting their day-to-day operation.

\subsubsection{Building Islamic Digital Social Ecosystem in Agricultural Value Chain}

"Yes, we have field officer to ensure our service will benefit the farmers... We are currently developing the data acquisition tools and process for better market information for the stakeholders especially farmers"

Crowde selected a group of farmers with field officer to ensure the farmer will get benefit from the ecosystem, gain trust from farmers, collect the payment, and input the farmer's data into the apps. Crowde uses external financing without any collateral to secure the credit process but use field officer to assist group of farmers for farming and collection process. Crowde only uses receivables and contract as guarantee for factoring or invoice financing to traders or off takers. It needs further technological development for collateral and guarantee for instance contract agreement from actors within the chain. In the process of integrating data from input supplier, farmer, and off taker the apps promote transparency and 
better decision process in agriculture value chain. This is one of the efforts to use technological innovation to enhance market competitiveness of agriculture value chain financing.

"We just launched our pilot project in 2018. Although a lot of contributor excited to fund the project, the farmer still reluctant due to their unfamiliarity with Islamic finance scheme..."

Recently, developing Islamic financing product, but still low adoption from farmers' side due to lack of awareness and knowledge about Islamic finance compared to conventional product. It needs further investigation to know more about the determinant for behavioral intention and how to increase adoption rate from farmers' side. Crowde only focuses on short-term investment product in agricultural financing by provide working capital to value chain actors. A gap provides access to finance to the low market segment and Islamic finance could provide several options such as zakah, waqf, and qard al-hassan,

"Yes, an INGO approaches us to build a partnership to increase farmer's access to finance. Still in progress..."

Social FinTech enterprise has potential to accelerate and support development agenda. This could be an opportunity to build an ecosystem of partnership with each core of abilities. FinTech do not have capability to increase the productivity through technical assistance while NGO has its own. Meanwhile, NGO does not have technology to increase the efficiency of ACVF process. It illustrates what kind of partnership could be built between the sectors and Islamic finance have unparalleled potential with Islamic social institution. However, this study only provides the digital ecosystem model to support this kind of partnership and will be discussed in section 4.3 .

\subsection{Islamic AVCF with FinTech Enabled Platform (AVCF-IF)}

Developing Islamic financial products in agriculture should incorporate various indicators such as profitability, public interest or social maslaha, and sharia compliant principle (Al-Salem, 2009; Cebeci, 2012; Todorof, 2018). The Agriculture Value Chain Finance Islamic FinTech will include the interconnected sub-sector value chain to build Islamic finance products for AVCF. Low market needs higher dependency for support entities, extension services, and assistance. The insights from market system development program and agriculture FinTech also will be addressed in policy implication from technology to support function aspect.

The value chain divided into three main actors, suppliers, producers, and market intermediaries in addition to three-market segmentation, low-income market, middle/upper income, and International market. The digital platform is linking agriculture value chain actors, landowners, funders, and end-consumer to propose fund, renting a land, to buy and sell input and commodities between input suppliers, farmers, market intermediaries, and end consumer. The core feature in this platform is not a farming digital marketplace, but providing Islamic modes of finance to enabling the transactions happen in one platform. For instance, a farmer needs local inputs from nearest input supplier, farmer choose the product available with deferred payment cost-plus contract, it will propose to community or institutional investor depends on the business days required, after that farmer 
could obtain the order directly from input supplier. Field officer depending on farmer's literacy on technology could represent this mechanism.

\subsubsection{Islamic AVCF Products}

Based on multiple case studies, the transaction processes between actors are translated into appropriate Islamic finance modes of finance. Islamic agriculture's financing focuses on production process which smallholder farmers and landowners with modes of finance such as muzara'a $\mathcal{E}$ mukhabara (Oladokun et al., 2015), and musharaka-mudaraba (Saqib et al., 2014). Also, some finances help poor smallholder farmers with productive zakat and qard al hassan (Obaidullah, 2015). Currently, Islamic FinTech in agriculture focusing to develop musharaka, murabaha, salam, and istisna contract to bridging the fund between investors and farmers. Meanwhile, the AVCF approach links all actors to increase the likelihood of high value production and expanding farmers' reach to export oriented market is considerably new in Agriculture FinTech. Figure 4 shows Islamic AVCF products to support FinTech enabled platform.

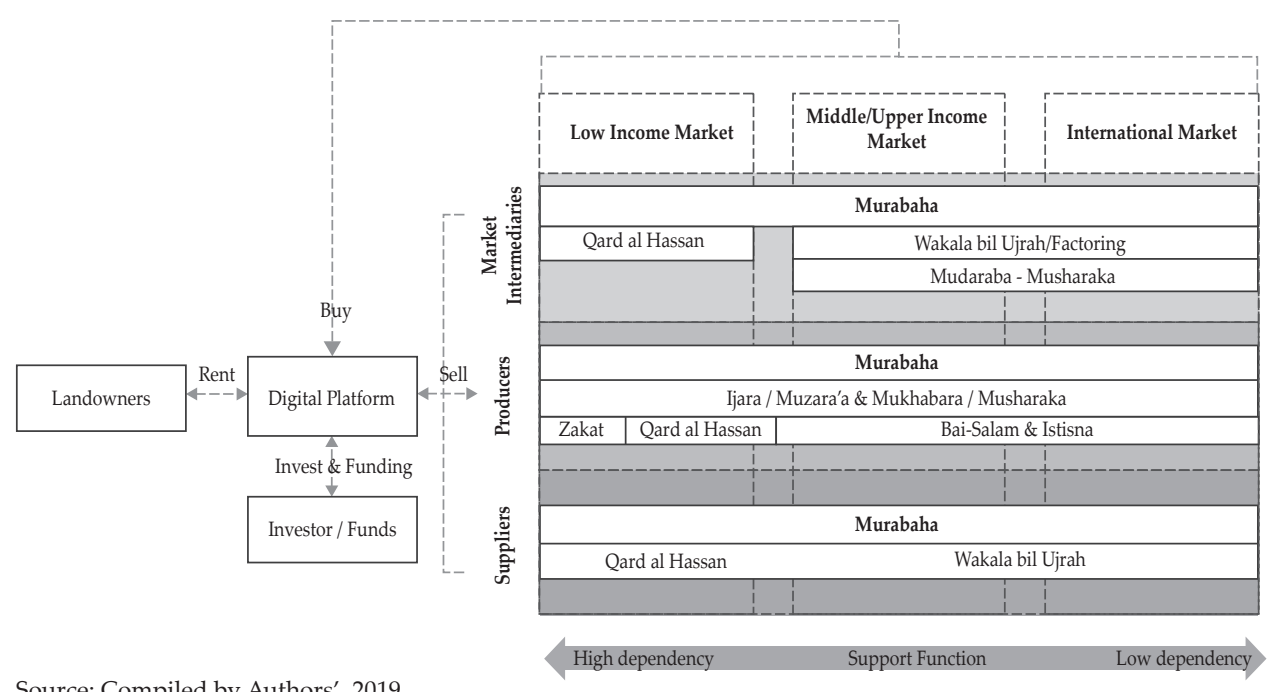

Source: Compiled by Authors', 2019

Figure 10.

Islamic Agriculture's Value Chain Finance Products with FinTech Enabled Platform

Firstly, in the process of AVCF, FinTech act as an intermediary or wakala for investors/funds to transfer the investment and in landowners' case to offer their land asset available that could be managed by producers based on project and available farmers on digital platform. Through AVCF approach, every layer of value chain in market segmentation has different types of modes. Low-income market segment is appropriate to be funded by donation, crowdfunding, and non-profit institutional fund i.e. productive zakat. Middle and upper is the most common market targeted by AgriTech where all types of investors could contribute 
to the project. Meanwhile, international market needed institutional investors i.e. non-banks financial institution and banks to accelerate the investment fulfillment instead of through crowdfunding scheme. Customarily, suppliers provide inputs to farmers based on demand and cycle for low-income market hence they do not have invoices available. Therefore, the most appropriate modes of finance are qard al hassan which offer debt financing without interest for low segment suppliers and murabaha where FinTech have partnership with input distributor to offer creditcost plus sales with deferred payment. Then, both productive zakat (Muslims' charity) and qard al hassan will support cost of inputs and other operations for lowest income farmers and mustahiq (people who allowed to receives zakat). Murabaha scheme also one of financing alternatives for low segment market to prevent inappropriate usage of lump sum money unlike zakat and qard al hassan but applies to non-mustahiq farmers. Such practices apply for traders in small or weekly market where qard al-hassan and murabaha output from farmers could be bought and sold with small profit if using deferred and credit payment. Otherwise, smallholder farmers could sell directly to the closest market within the value chain. This flexible payment schedule is to help low segment's cash flow until reach the targeted market without any excessive cost added to final price due to financing.

For suppliers in middle-upper and international market segment where most of them have contractual based to deliver inputs to the group of farmers and plantation, wakala bil ujrah or Islamic factoring financing is the most appropriate modes of finance. The difference between conventional invoice financing, the borrower only pays fixed fee for the financing services against account receivable not based on interest fee. This is to ensure good operating cash flow for the borrowers where its receivable payment schedules different with the day-today operation. Additionally, murabaha for buying supply also could be applied for this input supplier. The mechanism could be in form of murabaha lil amir bisy syira where the borrower order FinTech to buy the goods and sell with cost plus price, which could be applied to institutional investors instead of community. The payment schedule of murabaha could be deferred (muajjal) or credit payment. For land asset, landowners could offer their land to be managed by smallholder and farmers' group through muzara'a agreement if the landowner provide inputs to the smallholder farmers and mukhabara if the farmer use inputs from his own then the production output whether loss and profit will be shared according to the agreement. If mukhabara and muzara'a still face uncertainty with profit and loss sharing principle in some commodities, ijarah could be one of alternative scheme for landowner to offer his asset to the farmers by charge some fixed fee based on period of usage where the Fintech platform will inform the price to the farmer members in the platform.

Meanwhile, bai salam $\mathcal{E}$ istisna is practically different but have the same scheme where the smallholder or farmers' group received payment in advance for specific production. Bai salam has rigid time delivery and cannot be cancelled where borrower got full payment in advance. Istisna is a process-based contract and the borrower received the payment based on progress or another flexible payment. Then, Fintech platform will sell commodities to the market to receive the profit. This contract is specifically for producers who do not have access to the market intermediaries. For producers who have strong access to the market could 
propose musharaka contract to producing the commodities where both producer and investor have share of equity in the project meaning have proportional profit and loss sharing based on agreement where Fintech platform is the extension of investor to oversee the project through field officers or closest actors in value chain. Such an attempt requires rigor analysis and measurement from FinTech side to ensure the production capability, risk, and other variables are appropriate to implement this mode of finance. Hence, musharaka is suitable for middleupper and international segment with highly experienced producers. As already explained above how wakala bil ujrah and murabaha work, market intermediaries are compatible with the nature of those trade finance. The concept of mudaraba is a partnership between investor and manager in this context is market intermediary to run business trade. The difference between mudaraba and musharaka is the investor bears all risks while the market intermediary gets profit share. Therefore, the combination between mudaraba-musharaka contracts is established to reduce the risk between investor and wholesaler or broker. It means both could have proportionate capital also profit and loss sharing while Fintech platform have fewer roles in supervising the project.

\subsubsection{Digital Hub for Islamic Agriculture Value Chain Actors and Stakeholders}

Furthermore, technology could complement market system development to reduce the asymmetric information. Figure 11 illustrates a comprehensive digital hub for actors and stakeholders with market segmentation. This model includes development and commercial perspective for a more sustainable agriculture. This digital hub could integrate and mapping all actors in agriculture sector governed by network created by FinTech enabled platform (Agyekumhene et al., 2018).

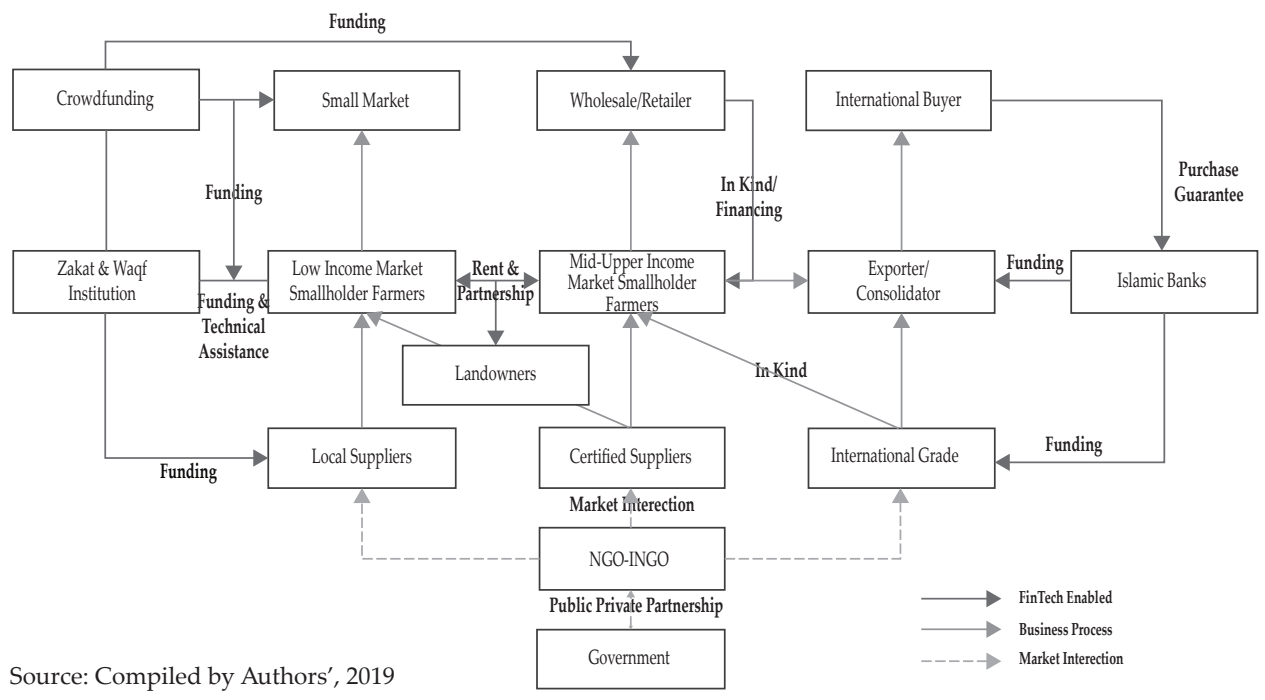

Figure 11.

Digital Hub for Actors and Stakeholders 
In addition, government could have a better view to formulate the agriculture policy and market intervention by oversee the information of ecosystem gathered from FinTech enabled platform (Agyekumhene et al., 2018). This could form a better development program through Public-Private Partnership to aim the Theory of Change. Making digital social entrepreneurs as intermediaries for PPPs could increase people and stakeholder engagement, address social needs that not well addressed by public policies, and as value added for technological innovation process of the business. (Battisti, 2019). Zakat and Waqf institutions also could formulate the technical assistance and program for low income market smallholder farmers with a more comprehensive value chain perspective not only silo perspective. Therefore, the excluded and relatively poor population could get benefit from access to finance even though there is another variable to increase the likelihood to build their entrepreneurial mindset and habit (Augsburg, De Haas, Harmgart, \& Meghir, 2015). As mentioned in section 4.3.1, qard al hassan and zakat modes could support the low market segment actors even development program and the current FinTech model does not have financial products to support the market segment. Landowners also could rent their land with ijara scheme. Both landowners and farmer who own the land could have access to other actors to form a partnership in muzara'a or mukhabara. Community based funding could support low market segment with infaq and waqf mode for social driven projects. On the other hand, they could also fund the middle-upper market project for commercial driven projects. They could have both social and commercial investment portfolio. Islamic banks could focus on financing the less risk and high profitability agriculture project such as upper and international market segment with a more complex form of contract. Meanwhile, the role of FinTech as the third party is to ensure that the transaction proceeds based on contracts and agreements as the data platform should be supported by advanced technology and infrastructure (Lynn et al., 2019; McIntosh \& Mansini, 2018). This digital hub model based on case study findings is to prove the possibilities are endless for Islamic Fintech platform to develop the agriculture sectors. Thus, from business practice to regulator could see this as high value opportunity to spur the growth of this sector through a network formed by FinTech enabled platform.

\section{CONCLUSION AND RECOMMENDATION}

\subsection{Conclusion}

This study emphasizes in the era of Fourth Industrial Revolution; digital technologies could be the solution to emerging social problems and one of them is agriculture. The digital innovation to link all agriculture's value chain actors from upstream to downstream segment is undoubtedly essentials to spur its growth and sustainable development. AVCF approach with FinTech enabled could be a very useful platform to enhance the flexibility with customer-centric products and services particularly to promote access to finance to AVCF actors. This study suggests that Islamic finance could contribute its financial development to all market segmentation and value chain actors from various fund sources and stakeholders. Although, AVCF FinTech could tackle some issues in asymmetric information and higher access to finance. To build the whole system of agriculture's value 
chain first is crucial before implementing this AVCF FinTech approach to ensure its market competitiveness and sustainability. This paper only discusses Islamic AVCF modes of finance based on market segmentation in FinTech. This conceptual framework has not been evaluated systematically and reviewed comprehensively in a form of experimental design.

\subsection{Recommendation}

Therefore, based on findings there are some important areas for further discussion, opportunities, and policy implication which are:

Digital technologies could be the solution to emerging social problems. In the era of Fourth Industrial Revolution, societies should ceaselessly ensure that no one left behind to promote socio-economic justice. The future research could assess in what extent digital technologies, could provide value added to development agenda in agriculture sector.

Another future research recommendation is determining behavioral intention for AVCF Islamic FinTech products. One of the issues is lack of farmers' knowledge and awareness about Islamic finance products, which leads to low adoption. It is important to determine the attitude towards buying intention to use Islamic finance and know what is hindering them to propose fund with Islamic finance compared to conventional products. Then, we could conclude the recommendation to increase the intention to use Islamic agricultural finance product and catering their needs into the product development and user experience.

In addition, the importance of development of technology support and architecture. To implement the Islamic segmented AVCF needs further and sophisticated development in technology features i.e. AI, blockchain, digital marketplace, smart contract, digital wallet and payment as well as system support i.e. InsurTech, RegTech (Hinson et al., 2019; Lynn et al., 2019). One of crucial technology for enabling AVCF-IF is smart contract. The use of block chain technology to integrate all transaction in one chain of data to ensure the implementation is compliant with the contract. The sharia-compliant smart contracts and other technological innovation for agriculture value-chain financing need further investigation. Those technologies could increase the operational efficiency for business practitioners in AVCF.

The important highlight where the regulator could play important role is partnership establishment of extension services and support entities. Institutional between public and private collaboration to pave the way social and commercial side of this business model is needed, for instance zakat and waqf or blended finance scheme for a more sustainable solution (OECD, 2018; Rankin et al., 2018; Rode et al., 2019). These institutions could act as assistance for low market segment to develop their capabilities and productivity until certain level while FinTech reaches out to more funders or donors. Until the value chain actors gain lower dependency and higher income, they could move to Islamic finance product for middle/upper market segment. The institutional cooperation should have further governance, regulatory, and operation model to ensure its implementation. 


\section{REFERENCES}

Abdul Rahman, R., Muhammad, A. D., Ahmed, S., \& Amin, F. (2016). Microentrepreneurs' intention to use Islamic micro-investment model (IMIM) in Bangladesh.Humanomics,32(2),172-188.https://doi.org/10.1108/H-02-2016-0020

Agyekumhene, C., de Vries, J. R., van Paassen, A., Macnaghten, P., Schut, M., \& Bregt, A. (2018). Digital platforms for smallholder credit access: The mediation of trust for cooperation in maize value chain financing. NJAS Wageningen Journal of Life Sciences, 86-87(June), 77-88. https://doi.org/10.1016/j. njas.2018.06.001

Al-Salem, F. H. (2009). Islamic financial product innovation. International Journal of Islamic and Middle Eastern Finance and Management, 2(3), 187-200. https://doi. org/10.1108/17538390910986326

ANGIN. (2016). Social Finance Landscape in Indonesia. Retrieved from http://www. id.undp.org/content/dam/indonesia/2017/doc/INS-SF Report2 ANGIN.PDF

Anshari, M., Almunawar, M. N., Masri, M., \& Hamdan, M. (2019). Digital Marketplace and FinTech to Support Agriculture Sustainability. Energy Procedia, 156(2018), 234-238. https://doi.org/10.1016/j.egypro.2018.11.134

Augsburg, B., De Haas, R., Harmgart, H., \& Meghir, C. (2015). The Impacts of Microcredit: Evidence from Bosnia and Herzegovina. American Economic Journal: Applied Economics, 7(1), 183-203. https://doi.org/10.1257/app.20130272

Battisti, S. (2019). Digital Social Entrepreneurs as Bridges in Public-Private Partnerships. Journal of Social Entrepreneurship, 10(2), 135-158. https://doi.org/1 0.1080/19420676.2018.1541006

Briones, R. M. (2015). Small Farmers in High-Value Chains: Binding or Relaxing Constraints to Inclusive Growth? World Development, 72, 43-52. https://doi. org/10.1016/j.worlddev.2015.01.005

Casuga, M. S., Paguia, F. L., Garabiag, K. ., Santos, M. T. J., Atienza, C. S., Garay, A. R., ... Guce, G. M. Financial Access and Inclusion in the Agricultural Value Chain, 1 Asia-Pacific Rural and Agricultural Credit Association (APRACA), Thailand (2008). APRACA FinPower Publication.

Cebeci, I. (2012). Integrating the social maslaha into Islamic finance. Accounting Research Journal, 25(3), 166-184. https://doi.org/10.1108/10309611211290158

Chen, K., Joshi, P. K., Cheng, E., \& Birthal., P. S. (2015). Innovations in financing of agri-food value chains in China and India: Lessons and policies for inclusive financing. China Agricultural Economic Review, 7(4), 1-27.

Creswell, J. W. (2014). Research design: qualitative, quantitative, and mixed methods approaches (4th ed.). Thousand Oaks, CA: SAGE Publications.

Digal, L. N. (2007). Linking Small Scale Rural Producers to High Value Markets: the role of technical assistance and credit. In Southeast Asian Regional Conference on Agricultural Value Chain Financing (pp. 89-4). Kuala Lumpur: Asian Productivity Organization.

Donovan, J., Franzel, S., Cunha, M., Gyau, A., \& Mithöfer, D. (2015). Guides for value chain development: a comparative review. Journal of Agribusiness in Developing and Emerging Economies, 5(1), 2-23. https://doi.org/10.1108/ JADEE-07-2013-0025

Gyanendra Mani, \& Joshi, P. K. (2017). Financing Agricultural Value Chains: An Overview of Issues, Lessons Learnt, and Policy Implications. In Financing 
Agriculture Value Chains in India Challenges and Opportunities (pp. 3-14). Singapore: Springer Nature Singapore. https://doi.org/10.1007/978-981-105957-5_1

Hinson, R., Lensink, R., \& Mueller, A. (2019). Transforming agribusiness in developing countries: SDGs and the role of FinTech. Current Opinion in Environmental Sustainability, 41, 1-9. https://doi.org/10.1016/j.cosust.2019.07.002

Irz, X., Lin, L., Thirtle, C., \& Wiggins, S. (2001). Agricultural Productivity Growth and Poverty Alleviation Theoretical expectations of the effects of agricultural growth on poverty. Development Policy Review, 19(4), 449-466.

Jones, L. M. (Ed.). (2011). Value Chains and Development: Emerging Theory and Practice. Practical Action Publishing.

Kilelu, C., Klerkx, L., Omore, A., Baltenweck, I., Leeuwis, C., \& Githinji, J. (2017). Value Chain Upgrading and the Inclusion of Smallholders in Markets: Reflections on Contributions of Multi-Stakeholder Processes in Dairy Development in Tanzania. European Journal of Development Research, 29(5), 1102-1121. https://doi.org/10.1057/s41287-016-0074-z

Krippendorff, K. (2004). Content analysis: an introduction to its methodology (2nd ed.). Beverly Hills: SAGE Publications.

Kuhl, L. (2018). Potential contributions of market-systems development initiatives for building climate resilience. World Development, 108, 131-144. https://doi. org/10.1016/j.worlddev.2018.02.036

Lincoln, Y., \& Guba, E. (1985). Naturalistic Inquiry. Newbury Park, CA: SAGE Publications.

Lynn, T., Mooney, J. G., Rosati, P., \& Cummins, M. (Eds.). (2019). Disrupting Finance: FinTech and Strategy in the 21st Century. Cham: Springer International Publishing. https://doi.org/10.1007/978-3-030-02330-0

Mani, G., Joshi, P. K., \& Ashok, M. V. (Eds.). (2017). Financing Agriculture Value Chains in India. Singapore: Springer Singapore. https://doi.org/10.1007/978981-10-5957-5

McIntosh, C., \& Mansini, C. S. (2018). The Use of Financial Technology in the Agriculture Sector (ADBI Working Paper 872). Tokyo. Retrieved from https:// www.adb.org/publications/use-financial-technology-agriculture-sector

Meyer, R. L. (2002). The demand for flexible microfinance products: lessons from Bangladesh. Journal of International Development, 14(3), 351-368. https://doi. org/10.1002/jid.884

Meyer, R. L. (2007). Analyzing and Financing Value Chains: Cutting Edge Developments in Value Chain Analysis (pp. 20-23). Presentation at the 3rd African Microfinance Conference : New Options for Rural and Urban Africa.

Miles, M. B., \& Huberman, A. M. (1994). Qualitative data analysis: an expanded sourcebook (2nd ed.). Thousand Oaks, CA: SAGE Publications.

Miller, C. (2012). Agricultural Value Chain Finance Strategy and Design (Technical Note). Rome.

Miller, C., \& Jones, L. (2010). Agricultural Value Chain Finance: Tools and Lessons. Warwickshire: The Food and Agriculture Organization of the United Nations and Practical Action Publishing. 
Moh'd,I.S., OmarMohammed, M., \&Saiti, B. (2017). The problems facing agricultural sector in Zanzibar and the prospects of Waqf-Muzar'ah-supply chain model. Humanomics, 33(2), 189-210. https://doi.org/10.1108/H-02-2017-0033

Nicoletti, B. (2017). Introduction. In The Future of FinTech (pp. 1-2). Cham: Springer International Publishing. https://doi.org/10.1007/978-3-319-51415-4_1

Obaidullah, M. (2015). Enhancing food security with Islamic microfinance: insights from some recent experiments. Agricultural Finance Review, 75(2), 142-168. https://doi.org/10.1108/AFR-11-2014-0033

OECD. (2018). Making Blended Finance Work for the Sustainable Development Goals. OECD. https://doi.org/10.1787/9789264288768-en

OJK. (2019). Penyelenggara Fintech Terdaftar dan Berizin di OJK per 7 Agustus 2019. Retrieved September 8, 2019, from https://www.ojk.go.id/id/berita-dankegiatan/publikasi/Pages/Penyelenggara-Fintech-Terdaftar-dan-Berizin-diOJK-per-7-Agustus-2019.aspx

Oladokun, N. O., Larbani, M., \& Mohammed, M. O. (2015). The problems facing the agricultural sector in Nigeria and the prospect of Muzara'ah and supply chain model. Humanomics, 31(1), 18-36. https://doi.org/10.1108/H-11-2012-0022

Oxford Business Group. (2018). New areas for growth in Indonesia's agriculture sector. Retrieved January 6, 2019, from https://oxfordbusinessgroup.com/ overview/breaking-new-ground-small-scale-farming-and-mechanisedproduction-set-unlock-sector's-economic

Prabhakar, R. (2019). Financial Inclusion: A Tale of Two Literatures. Social Policy and Society, 18(1), 37-50. https://doi.org/10.1017/S1474746418000039

Prodanov, H. (2018). Social Enterpreneurship And Digital Technologies. Economic Alternatives, (1), 123-138.

Rankin, M., Nogales, E. G., Santacoloma, P., Mhlanga, N., \& Rizzo, C. (2018). Public Private Partnerships for Agricultural Transformation Trends and Lessons from Developing Countries. In J. Leitão (Ed.), The Emerald Handbook of Public Private Partnerships in Developing and Emerging Economies (pp. 191-219). Bingley: Emerald Publishing Limited.

Rode, J., Pinzon, A., Stabile, M. C. C., Pirker, J., Bauch, S., Iribarrem, A., ... Environmental, H. (2019). Why 'Blended Finance' could help transitions to sustainable landscapes : Lessons from the Unlocking Forest Finance project. Ecosystem Services, 37(April). https://doi.org/10.1016/j.ecoser.2019.100917

Salıngan, G. (2018). Unleashing the potential of Islamic finance and impact investing for the SDGs. Retrieved December 30, 2018, from http://www.undp. org/content/undp/en/home/blog/2018/Unleashing_the_potential_of_Islamic_ finance_and_impact_investing_for_the_SDGs.html

Saqib, L., Zafar, M. A., Roberts, K. W., Zafar, A., \& Khan, K. (2014). Mushārakah-A realistic approach to the concept in Islamic Finance and its application to the agricultural sector in Pakistan. Arab Law Quarterly, 28(1), 1-39. https://doi. org/10.1163/15730255-12341270

Shwedel, K. (2007). Value chain financing: A strategy for an orderly, competitive, intergrated market. In R. Quirós Rodríguez (Ed.), Agricultural value chain finance (pp. 11-27). Rome: FAO. 
Sugema, I., Bakhtiar, T., \& Effendi, J. (2010). Interest versus Profit-Loss Sharing Credit Contract: Effciency and Welfare Implications. International Research Journal of Finance and Economics, 45(45), 58-67.

Todorof, M. (2018). Shariah-compliant FinTech in the banking industry. ERA Forum, 19(1), 1-17. https://doi.org/10.1007/s12027-018-0505-8

Varangis, P. (2018). Agriculture Finance \& Agriculture Insurance. Retrieved December 30, 2018, from http://www.worldbank.org/en/topic/financialsector/ brief/agriculture-finance

Weber, R. (2013). Microfinance Beyond the Standard? Evaluating Adequacy and Performance of Agricultural Microcredit. In Microfinance 3.0 (pp. 139-154). Springer Berlin Heidelberg.

World Bank. (2008). Agriculture for Development. In World Development Report. Washington, DC: World Bank Group.

Yin, R. K. (2014). Case Study Research Design and Methods (5th ed.). Thousand Oaks, CA: Sage. 